\title{
CHILDREN AND YOUNG ADULTS FROM THE EARLY SARMATIAN BURIALS OF THE LOWER VOLGA REGION (PALEOPATHOLOGICAL PERSPECTIVE) ${ }^{1}$
}

\author{
Evgeniy V. Pererva \\ Volgograd Institute of Management, Branch of RANEPA, Volgograd, Russian Federation \\ Valentina Yu. Chistobaeva \\ Volgograd State University, Volgograd, Russian Federation
}

\begin{abstract}
This paper presents the results of a study of bone remains of impuberal individuals from the Early Sarmatian burial mounds located in the Lower Volga region. When working with bone remains, we analyzed frequency of occurrence of various stress indicators and other abnormalities, taking into account biological age of the individuals buried there.

The comparison of paleopathology results with the data from archaeological and ethnographic written sources made it possible to assess some aspects of the life of the early Sarmatian population. Thus, the number of children and adolescents in the early Sarmatian burials corresponds to the established paleodemographic standards proving the normal demographic situation in the paleopopulation. Reconstruction of nutrition patterns allows us to assert that breastfeeding in early Sarmatians was long. Meat and dairy products were the basis of the diet of both older children and adults. In the life of the population, there must have been occasional famine periods, for instance, due to livestock loss. The nomads' diet was limited to meat and milk products, did not provide proper nutrition and caused numerous diseases such as scurvy and porosis. Paleopathology data demonstrate the spread of helminthiases and various infections in the Sarmatians.

Key words: the Sarmatians, Early Iron Age, bioarchaeology, paleopathology, children, young adults, scurvy, anemia, dental diseases.

Citation. Pererva E.V., Chistobaeva V.Yu. Children and Young Adults from the Early Sarmatian Burials of the Lower Volga Region (Paleopathological Perspective). Vestnik Volgogradskogo gosudarstvennogo universiteta. Seriya 4, Istoriya. Regionovedenie. Mezhdunarodnye otnosheniya [Science Journal of Volgograd State University. History. Area Studies. International Relations], 2018, vol. 23, no. 2, pp. 32-45. DOI: https://doi.org/10.15688/ jvolsu4.2018.2.3
\end{abstract}

\section{НЕПОЛОВОЗРЕЛЫЕ ИНДИВИДЫ И ПОДРОСТКИ}

ИЗ ПОГРЕБЕНИЙ РАННЕСАРМАТСКОГО ВРЕМЕНИ НИЖНЕГО ПОВОЛЖЬЯ (ПАЛЕОПАТОЛОГИЧЕСКИЙ АСПЕКТ) ${ }^{1}$

\author{
Евгений Владимирович Перерва \\ Волгоградский институт управления - филиал РАНХиГС, г. Волгоград, Российская Федерация
}

Валентина Юрьевна Чистобаева

Волгоградский государственный университет, г. Волгоград, Российская Федерация

Аннотация. В работе представлены результаты комплексного палеоантропологического анализа костных останков неполовозрелых индивидов из подкурганных захоронений раннесарматского времени 
с территории Нижнего Поволжья. При работе с костными останками оценивалась частота встречаемости различных индикаторов стресса и некоторых патологических отклонений с учетом биологического возраста.

Сопоставление полученных результатов с данными письменных источников, археологии, этнографии и других данных дало возможность обсудить некоторые аспекты жизнедеятельности раннесарматских групп. Так, численность детей и подростков в раннесарматских захоронениях обнаруживает сходство с известными палеодемографическими стандартами. Реконструкция питания позволяет утверждать, что грудное вскармливание у ранних сарматов было длительным. У детей более старшего возраста, как и у взрослых, основу диеты составляли мясные и молочные продукты. В жизни населения, возможно, случались голодоморы. При падеже скота узкая мясомолочная специализация не оставляла шансов для полноценного питания, что способствовало появлению цинги. Данные палеопатологии указывают на распространение у кочевников гельминтозов и различных инфекций.

Ключевые слова: Сарматы, ранний железный век, биоархеология, палеопатология, дети, подростки, цинга, анемия, болезни зубов.

Цитирование. Перерва Е. В., Чистобаева В. Ю. Неполовозрелые индивиды и подростки из погребений раннесарматского времени Нижнего Поволжья (палеопатологический аспект) // Вестник Волгоградского государственного университета. Серия 4, История. Регионоведение. Международные отношения. - 2018. T. 23, № 2. - С. 32-45. (на англ.). - DOI: https://doi.org/10.15688/jvolsu4.2018.2.3

\section{Introduction}

A considerable number of scientific studies are devoted to the history of the Sarmatian population of the early Iron Age from the Lower Volga region. Archaeological research of the Sartmatian population is one of the many popular areas dealing with such issues as chronology, dating back, typology of material objects, study of ritual funerary monuments, etc. Another perspective is paleoanthropological research of the Sauromatic and Sarmatian tribes. Anthropology contributes to archaeology in answering questions on demographic and ethnic history, provides an opportunity to reconstruct the external and physical appearance of the nomads as well as to clarify various aspects of their lifestyle.

According to written and archaeological sources, the Sarmatians were nomads. In the works of ancient authors, we find information about their way of life, sources of income, appearance, about the specifics of nutrition and degree of belligerence of the nomads. Unfortunately, in written sources there is no information about children and their life in nomadic societies. They were not the main producers in the households, did not participate in either battles or military campaigns, were not involved in foreign policy relations. Nevertheless, children were included in economic activity of the tribe from the earliest age possible. Childhood was an important stage in the life of the nomads. According to psychological research, children exert a great influence on the adults around them.
At the same time, children, despite the obvious reality, live in their own world, in which the past and the present are perceived differently. Children are not small copies of adults; they have different attitudes, view of things, priorities and social ties. All this wealth of children's life cannot be restored by evaluating separately the literary evidence from archaeological data. Written sources are dedicated mostly to adults' achievements whereas archaeological data do not always correspond to modern understanding of reality, reflecting either religious ideas or beliefs in life after death, or studies on bone remains, which are only a testimony to the end of a person's life without cultural interpretation. The only effective way to study children's way of life in ancient populations is to apply comprehensive approach and archaeological, anthropological and ethnographic data analysis.

In this paper, we attempt to identify some specific aspects of life based on the analysis of literary evidence, paleopathological, archaeological and ethnographical data related to immature individuals and adolescents in the early Sarmatian times.

\section{Research methods and material}

In this paper, the authors analyze bone remains of children and adolescents from the burials of 400$100 \mathrm{BC}$ of the Lower Volga region (Fig. 1).

In the course of the study, we made paleopathological examination of human bone 
remains using a descriptive macro morphological technique by A. Buzhilova to assess their pathological condition $[16 ; 17]$. We looked at the frequency of occurrence of the porotic hyperostosis of the orbitals (also known as "cribra orbitalia") and the cranial vault bones, signs of inflammatory processes on the bones of the postcranial skeleton in the form of periosteum inflammation. Inflammation on the inner surface of the cranial vault bones, dental diseases, and traumas were also taken into account. We assessed age-specific features of the study groups, as well as age dependencies of the spread of diseases. Wherefore, all the bone remains are categorized according to the age into infants (012 months), early childhood or toddlers (13 years); first children (4-7 years), second children (8-12 years) and adolescents (12-16 years) [11]. The material for this paper is represented by bone remains of 58 individuals (including 48 children's and 10 adolescents 'skeletons) (Table 1). The degree of integrity of the research material differs considerably: 52 bone remains contained relatively well-preserved scull capsules, while in 34 cases, only bones of postcranial skeletons.

\section{Description of research findings}

The composite sample consists of samples of the early Sarmatian children. Infant mortality rate is $28 \%$ of the total sample size (Table 1) which generally correlates with previously obtained research data $[3-5 ; 7 ; 49]$. The second time the early Sarmatian children's death rate peaks is during the "first childhood" at the age of 4-7. 1-3 year-old toddlers and 12-16 year-old adolescents died less frequently. The smallest in number only $14 \%$ cases of the total sample is the "second childhood" group that is children aged 812 (Table 1).

Table 1

Age features of the investigated series of the Early Sarmatian time

\begin{tabular}{|l|r|c|}
\hline \multicolumn{1}{|c|}{ Age } & \multicolumn{1}{c|}{$\mathrm{n}$} & $\%$ \\
\hline Infancy to 1 year & 16 & $28 \%$ \\
\hline Early childhood 1-3 years & 10 & $18 \%$ \\
\hline First Childhood 4-7 years & 15 & $22 \%$ \\
\hline Second Childhood 8-11 years & 7 & $14 \%$ \\
\hline Teenager 12-16 years & 10 & $18 \%$ \\
\hline \multicolumn{2}{|c|}{ Total } & 58 \\
\hline
\end{tabular}

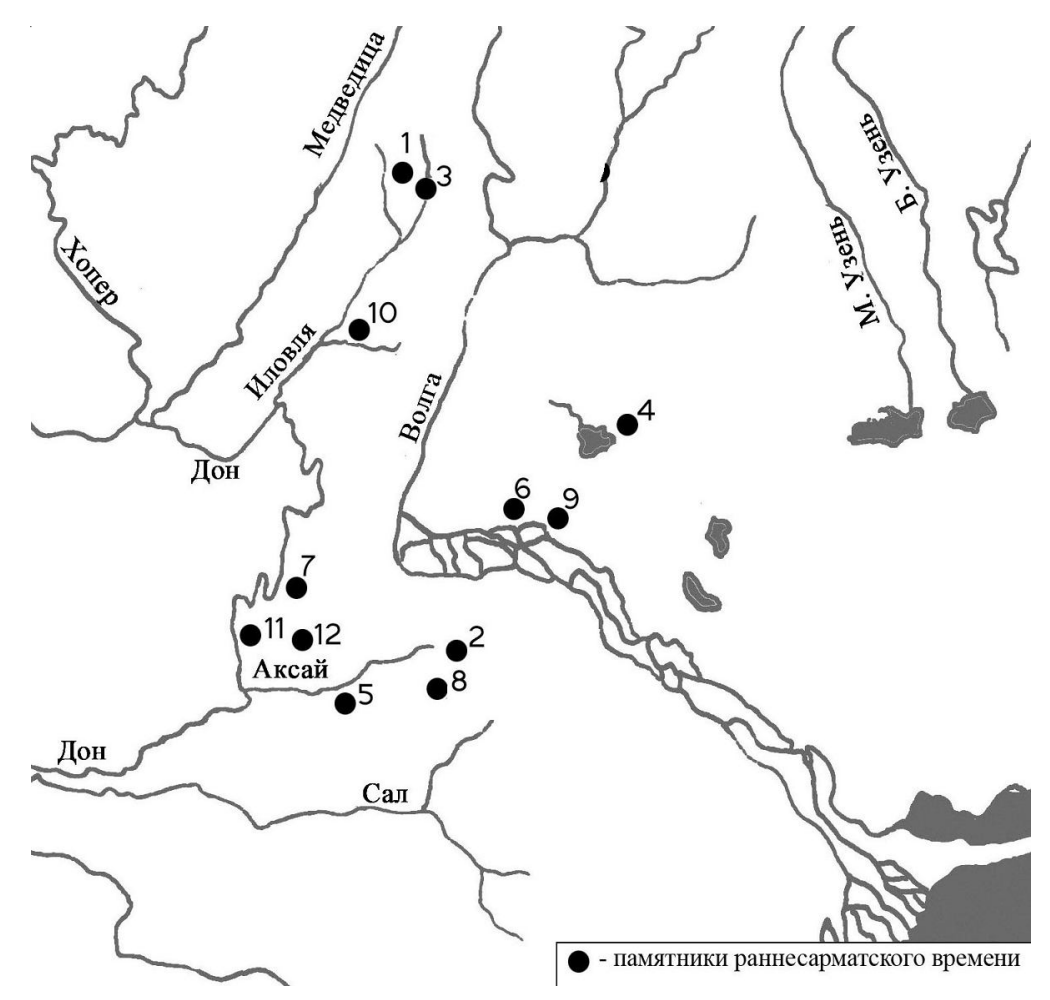

Fig. 1. Arrangement of the archaeological monuments from which the research materials originate:

1 - Avilovsky II; 2 - Aksai; 3 - Baranovka; 4 - Vengelovka; 5 - Kovalevka; 6 - Maliaevka; 7 - Pervomaysky; 8 - Peregruznoe; 9 - Solodovka; 10 - Tary; 11 - Shebalino; 12 - Gromoslavka 
One tooth decay case was identified in a Sarmatian teenager aged 12-14 from the burial 1 of mound 10. We consider this pathology in the Early Sarmatian group to be a random finding, and not as a permanent marker of unfavorable adaptation.

In early Sarmatian children, dental tartar is often observed on milk teeth developing frequently during the early childhood (1-3 years) (Fig. 2, Table 3 ). The peak of calculus occurs at later stages of growth (Table 3 ). Similar result in tartar formation is observed in other children's groups, for example, of the Bronze Age and the Early Iron Age from the Lower Volga Region [49-51].

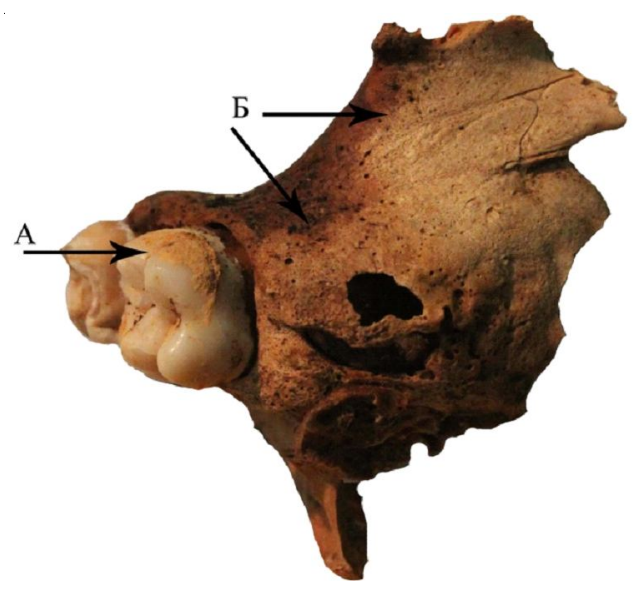

Fig. 2. Light yellow tartar deposits on the upper jaw molar $(A)$ traces of the maxillary bone porosity $(B)$ in the child from burial 4 of the burial mound Kovalevka

Enamel hypoplasia in the early Sarmatian children manifests itself in the form of horizontal lines (thinning of the enamel layer) on the surface of the enamel of permanent teeth (Fig. 3). Its occurrence is relatively low, about $16.7 \%$ (Table 2). Evaluation of age dependences of the enamel hypoplasia testifies to its growth on the teeth of children proportionally to their age, reaching its peak, as in the case of tartar, in the adolescent group (Table 3).

In the series of the early Sarmatian children, cases of porotic hyperostosis, also known as osteoporosis symmetrica (hereinafter "PH") of the orbits (hereinafter "cribra orbitalia" or "CO") and of the cranial vault bones are revealed. This indicates that these individuals suffered from iron deficiency (Fig. 4, 5). Cribra orbitalia has been detected in more than half of the children, and the porotic hyperostosis of the cranial vault bones in $42.6 \%$ of the children series (Table 2).

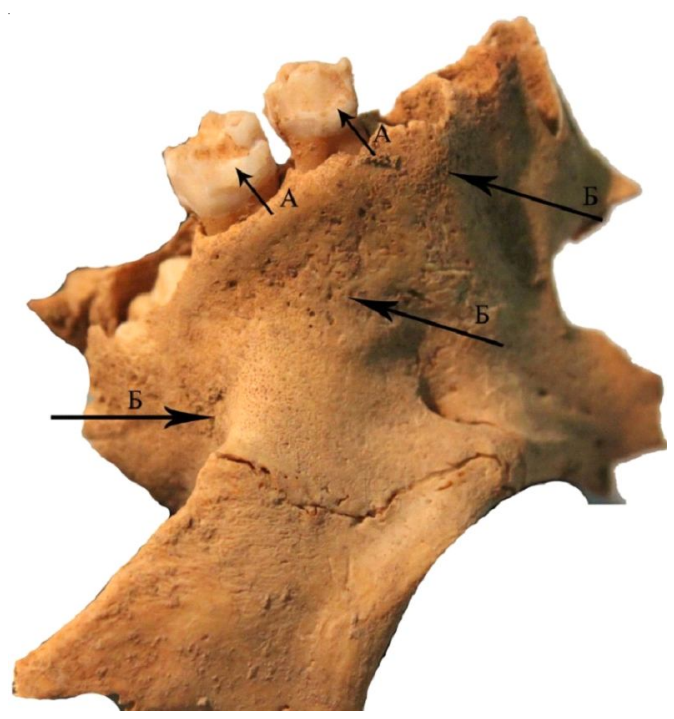

Fig. 3. Enamel hypoplasia in the form of dimples and spots on the molars $(A)$, the porcelain of the left maxillary bone and the alveolar margin of the upper jaw $(B)$ of the child from burial 7 of the burial mound Kovalevka

Table 2

The occurrence

of some pathological conditions on the skull and skeleton

\begin{tabular}{|l|c|r|r|}
\hline \multicolumn{1}{|c|}{ Pathologies } & S & \multicolumn{1}{c|}{ N } & \multicolumn{1}{c|}{$\%$} \\
\hline Digital impressions & 54 & 19 & 35,2 \\
\hline Caries & 54 & 1 & 1,9 \\
\hline Tooth calculus & 54 & 22 & 40,7 \\
\hline Enamel hypoplasia & 54 & 9 & 16,7 \\
\hline Porosis & 54 & 34 & 62,9 \\
\hline Cribra orbitalia & 54 & 28 & 51,9 \\
\hline Porotic hyperostosis & 54 & 23 & 42,6 \\
\hline Inflammations on skull & 54 & 5 & 9,3 \\
\hline Periostitis & 36 & 11 & 30,6 \\
\hline Postmortem changes & 58 & 1 & 1,7 \\
\hline Trauma & 54 & 2 & 3,7 \\
\hline
\end{tabular}

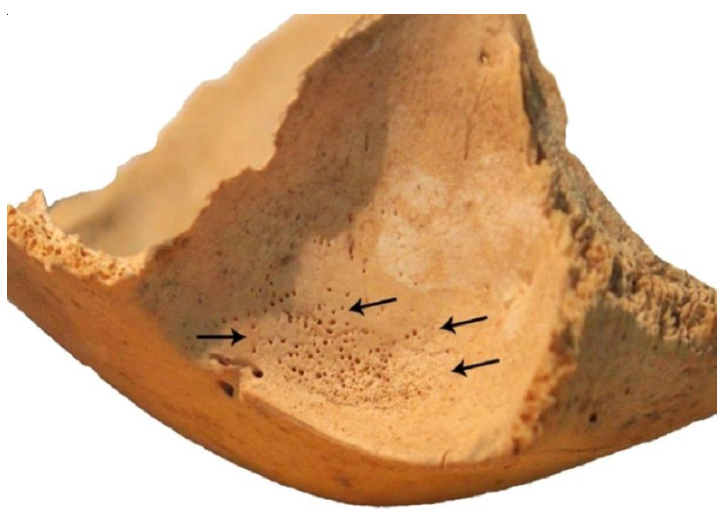

Fig. 4. "Cribra orbitalia" - a porous hyperostosis of the orbits of a child from the burial of mound 11 of the burial mound Kovalevka 


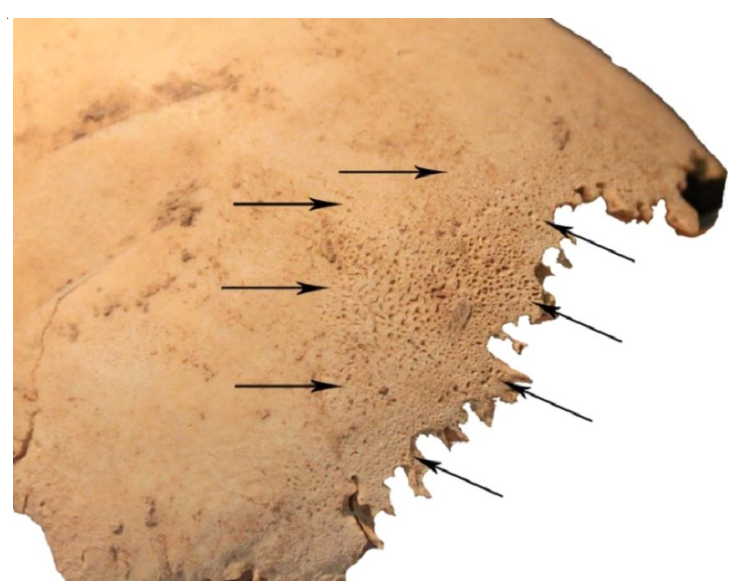

Fig. 5. Porotic hyperostosis of the cranial vault bones in the child from the burial of mound 11 of the burial mound Kovalevka

Porosis turned out to be the most common of all pathological conditions on the cranial vault bones and the postcranial skeleton in the immature population studied, its occurrence rate reaching $62.9 \%$ (Table 2; Fig. 2, 3). Despite the fact that it can be observed in all the immature age groups, there is a clear dynamics of its occurrence in the rate inversely proportional to age. Therefore, in individuals of 8-11 years old and in adolescents, the porosis level reaches $40 \%$ (Tables 3, 4). The highest porosis frequencies manifest in the toddler group ( 1 to 3 years) where they reach $100 \%$ (Table 3).

Table 2 presents analysis of age dependences of porosis lesion of different parts of the skeleton. It was found that the intensity of signs of sparsity of bone tissue decreases with age. In the early Sarmatian children, the porosis is most often observed on the alveolar process of the lower jaw, on the inner surface of the alveoli of the teeth and on the branches of the lower jaw from the inside. Somewhat less frequently, the porosis appears on the upper alveolar process and in its alveoli, and on the hard palate (Table 3 ).

The porosis signs are less frequently identified on the postcranial skeleton. They are almost completely absent in the older children group (aged 8-12) and in adolescents. In the remaining age groups, the rarefaction or sparsity of bone tissue occurs on the scapula and on the diaphysis of the long bones of the skeleton.

We reveal and classify into two categories manifestations of inflammatory processes in children of 400-100 BC. The first category is hemorrhages and periostitis on the skull bones while the second one is presented by periostitis of the bones of the postcranial skeleton. The incidence rate of inflammation in these groups of pathologies differs from $9.3 \%$ on the skull to $30.6 \%$ on the bones of the extremities, pelvis and trunk (Table 2).

Pathological conditions such as hemorrhages of the inner surface from the side of the endocast were found in all children with traces of the inflammatory process on the skull (Fig. 6). In the majority of cases, these pathologies accompany porosis or porotic hyperostosis, periostitis of the upper and lower extremities, indicating their systemic nature.

Table 3

Age dependence in the manifestation of some pathological conditions in the early Sarmatian period

\begin{tabular}{|l|c|c|c|c|c|}
\hline \multirow{3}{*}{ Pathology/Age } & Infancy & $\begin{array}{c}\text { Early } \\
\text { Childhood }\end{array}$ & $\begin{array}{c}\text { First } \\
\text { Childhoo } \\
\mathrm{d}\end{array}$ & $\begin{array}{c}\text { Second } \\
\text { Childhoo } \\
\mathrm{d}\end{array}$ & Teenager \\
\cline { 2 - 6 } & $\begin{array}{c}\mathrm{N} / \% \\
15 / 11 *\end{array}$ & $\begin{array}{c}\mathrm{N} / \% \\
10 / 6\end{array}$ & $\begin{array}{c}\mathrm{N} / \% \\
14 / 10\end{array}$ & $\begin{array}{c}\mathrm{N} / \% \\
5 / 3\end{array}$ & $\begin{array}{c}\mathrm{N} / \% \\
10 / 6\end{array}$ \\
\hline Trauma & $0 / 0 \%$ & $0 / 0 \%$ & $0 / 0 \%$ & $0 / 0 \%$ & $2 / 20 \%$ \\
\hline Caries & $0 / 0 \%$ & $0 / 0 \%$ & $1 / 7,1 \%$ & $0 / 0 \%$ & $1 / 10 \%$ \\
\hline Digital impressions & $0 / 0 \%$ & $3 / 30 \%$ & $7 / 50 \%$ & $5 / 100 \%$ & $4 / 40 \%$ \\
\hline Tooth calculus & $0 / 0 \%$ & $2 / 20 \%$ & $8 / 57,1 \%$ & $4 / 80 \%$ & $8 / 80 \%$ \\
\hline Enamel hypoplasia & $0 / 0 \%$ & $1 / 10 \%$ & $3 / 21,4 \%$ & $1 / 20 \%$ & $4 / 40 \%$ \\
\hline Porosis & $10 / 66,7 \%$ & $10 / 100 \%$ & $8 / 57 \%$ & $2 / 40 \%$ & $4 / 40 \%$ \\
\hline Cribra orbitalia & $8 / 53,3 \%$ & $7 / 70 \%$ & $9 / 64,3 \%$ & $1 / 20 \%$ & $3 / 30 \%$ \\
\hline Porotic hyperostosis (skull) & $10 / 66,7 \%$ & $3 / 30 \%$ & $6 / 42,9 \%$ & $1 / 20 \%$ & $3 / 30 \%$ \\
\hline Haemorrhage & $2 / 13,3 \%$ & $2 / 20 \%$ & $0 / 0 \%$ & $0 / 0 \%$ & $1 / 10 \%$ \\
\hline Periostitis & $5 / 45,4 \%$ & $2 / 33 \%$ & $2 / 20 \%$ & $0 / 0 \%$ & $2 / 33,3 \%$ \\
\hline
\end{tabular}
skeletons.

* The first value refers to the number of studied skulls, and the second value - to the number of postcranial 
E.V. Pererva, V.Yu. Chistobaeva. Children and Young Adults from the Early Sarmatian Burials of the Lower Volga

Table 4

Distribution of the porosis and other pathological conditions in the total and age groups of the early Sarmatians

\begin{tabular}{|l|c|c|c|c|c|c|c|c|c|c|c|c|c|c|}
\hline \multirow{2}{*}{ Characteristic/Ages } & \multicolumn{2}{|c|}{ Total } & \multicolumn{2}{c|}{ Infancy } & \multicolumn{2}{c|}{$\begin{array}{c}\text { Early } \\
\text { Childhood }\end{array}$} & \multicolumn{2}{c|}{$\begin{array}{c}\text { First } \\
\text { Childhood }\end{array}$} & \multicolumn{2}{|c|}{$\begin{array}{c}\text { Second } \\
\text { Childhood }\end{array}$} & \multicolumn{2}{|c|}{ Teenager } \\
\hline Total/individuals & $\mathrm{N}$ & $\%$ & $\mathrm{~N}$ & $\%$ & $\mathrm{~N}$ & $\%$ & $\mathrm{~N}$ & $\%$ & $\mathrm{~N}$ & $\%$ & $\mathrm{~N}$ & $\%$ \\
\cline { 2 - 18 } & $54 / 36$ & \multicolumn{1}{|c|}{$15 / 11$} & \multicolumn{2}{|c|}{$10 / 5$} & \multicolumn{2}{|c|}{$14 / 9$} & \multicolumn{2}{|c|}{$5 / 3$} & \multicolumn{2}{c|}{$10 / 6$} \\
\hline $\begin{array}{l}\text { Porotic hyperostosis } \\
\text { on skull }\end{array}$ & 23 & 42,6 & 10 & 66,7 & 3 & 30 & 6 & 42,9 & 1 & 20 & 3 & 30 \\
\hline Cribra orbitalia & 27 & 50,0 & 8 & 53,3 & 7 & 70 & 7 & 50 & 2 & 40 & 3 & 30 \\
\hline Back infraorbital part & 15 & 27.8 & 4 & 26,7 & 8 & 80 & 2 & 14,3 & 0 & 0 & 1 & 10 \\
\hline Cheekbone & 14 & 25,9 & 3 & 20 & 7 & 70 & 2 & 14,3 & 1 & 20 & 2 & 20 \\
\hline Underorbital foramina & 8 & 14,8 & 3 & 20 & 4 & 40 & 1 & 7,1 & 1 & 20 & 0 & 0 \\
\hline $\begin{array}{l}\text { Alveolar appendix of } \\
\text { maxilla }\end{array}$ & 19 & 35,2 & 4 & 26,7 & 8 & 80 & 4 & 28,6 & 1 & 20 & 3 & 30 \\
\hline Alveol of maxilla & 17 & 31,5 & 3 & 20 & 8 & 80 & 3 & 21,4 & 1 & 20 & 3 & 30 \\
\hline Sphenoid & 9 & 16,6 & 5 & 33,3 & 2 & 20 & 2 & 14,3 & 1 & 20 & 0 & 0 \\
\hline Temporal bone & 10 & 18,5 & 4 & 26,7 & 1 & 10 & 4 & 28,6 & 0 & 0 & 2 & 20 \\
\hline Palate & 12 & 22,2 & 3 & 20 & 7 & 70 & 2 & 14,3 & 1 & 20 & 0 & 0 \\
\hline $\begin{array}{l}\text { Inflammation of } \\
\text { Durra matter }\end{array}$ & 5 & 9,3 & 2 & 13,3 & 2 & 20 & 0 & 0 & 0 & 0 & 1 & 10 \\
\hline $\begin{array}{l}\text { Coronoid process } \\
\text { of mandibula }\end{array}$ & 15 & 27,8 & 5 & 33,3 & 5 & 50 & 4 & 28,6 & 1 & 20 & 1 & 10 \\
\hline $\begin{array}{l}\text { Alveolar appendix of } \\
\text { mandibula }\end{array}$ & 23 & 42,6 & 8 & 53,3 & 9 & 90 & 3 & 21,4 & 1 & 20 & 3 & 30 \\
\hline $\begin{array}{l}\text { Alveolus of } \\
\text { mandibula }\end{array}$ & 13 & 24,1 & 6 & 40 & 5 & 50 & 1 & 7,1 & 1 & 20 & 1 & 10 \\
\hline $\begin{array}{l}\text { Shoulder bone } \\
\text { part of } \\
\text { Supra spinous fossa }\end{array}$ & 6 & 16,7 & 4 & 36,4 & 3 & 50 & 0 & 0 & 0 & 0 & 0 & 0 \\
\hline $\begin{array}{l}\text { Shoulder bone part of } \\
\text { Infra spinous fossa }\end{array}$ & 5 & 13,9 & 4 & 36,4 & 2 & 33,3 & 0 & 0 & 0 & 0 & 0 & 0 \\
\hline Porosis on ribs & 5 & 13,9 & 4 & 36,4 & 2 & 33,3 & 0 & 0 & 0 & 0 & 0 & 0 \\
\hline Porosis of metaphysis & 3 & 8,3 & 2 & 18,2 & 1 & 16,7 & 0 & 0 & 0 & 0 & 0 & 0 \\
\hline Porosis of epiphysis & 7 & 19,4 & 3 & 27,3 & 2 & 33,3 & 1 & 10 & 1 & 33,3 & 0 & 0 \\
\hline Porosis of diaphysis & 11 & 30,5 & 5 & 45,5 & 2 & 33,3 & 3 & 30 & 1 & 33,3 & 1 & 16,7 \\
\hline
\end{tabular}

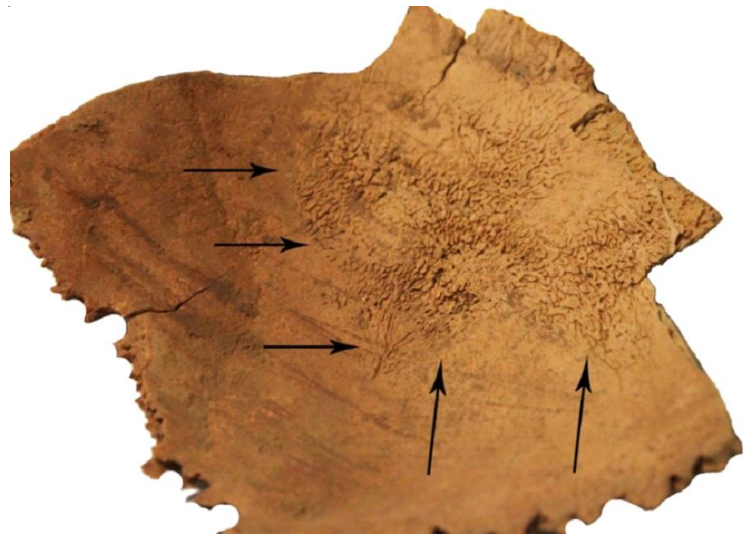

Fig. 6. Hemorrhages on the parietal bone of the child from burial 14 of mound 4

of the burial mound Kovalevka

11 cases of periostitis were identified on the bones of the postcranial skeleton. Most often (in $45 \%$ of cases) they were manifested in infants. Its occurrence rate reduces to $33 \%$ in early childhood group. In 9 children, signs of inflammation accompanied porotic hyperostosis of the skull bones.

In the study group, two cases of traumatic injury were observed. Both severe traumatic episodes were caused to skull with the sudden introduction of a blunt round instrument used with great force. There were no signs of perforation into the cranial cavity, but clear traces of healing, i.e. the trauma had a favorable outcome. All the lesions are on the cranial vault bones of adolescents aged 12-15 found in burials located in the Oktyabrskaya area of the Volgograd region.

\section{Discussion of research outcomes}

Age analysis of the study series of the Early Sarmatian period shows that the majority of 
children (46\%) died before they reached the age of 3 . The proportion of infants in the study group corresponds to observations and averaged indicators proper to the early Sarmatian culture (10-50\%). In general, compared with the Middle and Late Sarmatian times, burial mounds of 400 $100 \mathrm{BC}$ in the Lower Volga region contain a high number of children's graves; the authors $[4 ; 6 ; 8]$ have already noted this fact. We assume that a large percentage of children's burials in the archaeological complexes of the Early Sarmatian time is a tradition to bury all dead children under the mounds [5, p. 301]. As M.A. Balabanova indicates referring to the research by D. Brothwell [13] and G.P. Romanova [55], infant mortality in traditional cultures amounted to 30$70 \%$. Therefore, children and adolescent anthropological material of the Early Sarmatian sample almost completely corresponds to the normal demographic parameters [6, p. 134].

When examining dental pathologies, it was possible to identify the period of transition from breastfeeding to solid adult diet. Arguably, the Sarmatian children were nursed for quite a long period up to the age of 3-4. Since the first childhood and later on, more than a half of the children developed tartar on the crowns of their milk teeth, which indicates the transition to solid adult diet. Vascular dependence of the spread of enamel deficiency on permanent incisors and canines confirms the age of transition to the adult diet at the age of 3-4.

As stated in ancient archaeological and ethnographic literature, the diet of the Sarmatian, like of most nomads, consisted of meat and dairy products, rich in protein. According to Claudius Elian, Strabo, Pliny the Elder, the Sarmatians were mainly fed by products of animal origin such as meat, mare's milk, animal blood, cheese, sour-milk products or wild animals $[31 ; 60 ; 52]$.

The archaeologists found bone remains of a sheep carcass, less often of cattle or a horse in the early Sarmatian graves as burial and funerary ritual food. Phosphorus compound analysis of the bottom part of the soil from funeral vessels indicates that the pots in Sarmatian burials were filled with milk and meat broth [21].

N.L. Zhukovskaya describes dietary features of the nomads of Central Asia (the Mongols, the Uigurs, the Tibetans, the Kazakhs, the Kirghiz) at the end of the $19^{\text {th }}$ - beginning of the $20^{\text {th }}$ centuries. She indicates that in summer, the nomads had mainly dairy and in winter meat food [68, p. 65-66].

The diet of the adult population is arguably similar to the children's switched from breastfeeding to solid food. This is confirmed by the extremely low incidence of caries on the teeth of children and the widespread occurrence of calculus in the series. The dominance of protein diet of the Sarmatian adolescents and children was proved by the dentoalveolar system pathologies revealed in the population of the Stone Age and in the Bronze Age of the Kuban, of the Early and Middle Bronze Age of the Lower Volga Region groups, and also among the early Scythians from the mound of Novozavedennoe-II [22; 49; 41]. This proves that the nomad children and adults had predominantly protein diet.

Periods of famine had a serious impact on the health of children and adolescents of the early Sarmatian period. The proof that the nomads had difficult times can be found in written sources, in ethnographic literature, as well as in modern anthropological research.

This is how the ancient authors described the nomads during periods of famine: "The Sarmat, starved to death, was fed with the blood from the veins of his horse, sometimes mixing it with milk" [48, p. 280-283]. Remembering the periods of starvation, the Sauromat-Sarmat “... gorged every three days..." [34, p. 215-314; 32]. Aulus Helium (200 AD) writes: "The Scythians have a habit when for some time they are forced to remain without food, they pull tight the belly with wide belts, since in this way, hunger does not torment them" [35, p. 235].

Ethnography describes periods of famine of the nomadic peoples' when not only meat, guts and blood, but hoofs and bones of animals were used as food [10]. In addition, the nomads had occasionally to eat carrion, i.e. animals that had starved to death or had died from diseases. It happened to the nomads in different historical periods: the Scythians starved in $500 \mathrm{BC}$, the Mongols in $800 \mathrm{AD}$, the Crimean Tatars in $160-170 \mathrm{AD}$, the Kalmyks even in 190 AD [27; 54; 44; 67].

Lack of food in the Sarmatian period was associated with winter fodder shortage so called jutes. M.A. Balabanova points out that the Sarmatians had difficult years when death rate of sheep and horses herds was high [4, p. 8]. The 
loss of the main source of food in the cold periods was a real calamity for the nomads. The reasons for the loss of livestock differs from increased depth and density of snow, protracted winters, to thick ice crust and prolonged storms. All this combined with the natural and geographical peculiarities of the region, when every second or third year is usually arid and low-yielding. Under the circumstances, livestock losses and murrains occurred almost every five years, leading to long starvation periods in the life of the nomads, complicating their already difficult life [66, p. 41].

Scurvy was an aftereffect of hunger periods occurring in the nomads of 400-100 BC; it can be traced in children's skeletons. The evidence shows porosis on bone tissue of more than half of the bone remains is also a consequence of the life style. Most paleopathologists agree that the rarefaction of bone tissue in the form of a porosis on the bones of the arch and the facial part of the skull, as well as on the postcranial skeleton, can indicate the lack of vitamin $\mathrm{C}$ in diet $[45 ; 46 ; 42$; $12 ; 64 ; 14 ; 57 ; 26 ; 50 ; 51]$.

D. Ortner identified a number of specific markers on the skeleton indicating scurvy such as porosis of the cranial vault bones and large wings of the sphenoid, of the posterior part of the maxillary bone, of the hard palate and the alveolar processes of the upper and lower jaw, of the mandibular branches from the inside and the metaphyseal zones on the long bones of the limbs, as well as in the supraspinous and subacute pits of the scapula $[45 ; 46]$.

The picture of porotic abnormities on the skull bone and postcranial skeleton in the Early Sarmatian children almost completely corresponds to the pattern of scurvy lesion described by D. Ortner and other authors on nomadic paleopathological materials $[40 ; 37 ; 24 ; 27 ; 9 ; 20]$. Scurvy is caused by insufficient intake of vitamin $\mathrm{C}$ from food or a violation of its absorption. In children, this disease is referred to as MöllerBarlow disease $[45$, p. $213 ; 15$, p. 495]. The condition was caused by a decrease in immunity due to physical and psychological stress, on the one hand, and by lack of fresh food such as herbs, fruits, meat, milk, on the other [38, p. 255]. As $\mathrm{S}$. Mays points out, if the diet does not contain vitamin $\mathrm{C}$, its severe deficiency causes first symptoms of the disease in 1-3 month period of avitaminosis, while massive hemorrhages appear in 6 months [40, p. 178]. Thus, signs of a porosis recorded on the bone remains of children, may well be the result of prolonged seasonal famine. In addition, vitamin deficiency could have been complicated by other diseases and the negative factors impact.

Let us dwell on another pathological condition a vicious or porotic hyperostosis $(\mathrm{PH})$. We observed cases of vicious hyperostosis of the orbits (cribra orbitalia) and hyperostosis of the cranial vault bones in the studied material of the Early Sarmatian time. They are usually associated with the development of anemia in humans [61; $18 ; 56$, p. $273 ; 65$, p. $119 ; 69 ; 64$, p. $136 ; 62$, p. 75 ; 33 , p. 95]. According to P. Stewart-McAdam (1992) and J. Dale (1994), extensive professional literature reviews on etiology of the pathological condition. It is observed on human bones already at the earliest stages of the development. At the moment, there are several hypotheses that explain the occurrence of porotic hyperostosis in human populations. It can be the result of nutrition disturbance or "food stress" $[2 ; 27 ; 31 ; 43]$. $\mathrm{O}$. Hegen expresses the opinion that VP is a consequence of iron-deficient anemia caused by malnutrition in combination with infectious and parasitic diseases [29, p. 57-76]. Porotic hyperestrosis develops as a consequence of vitamin B12 deficiency in the body [65]. According to F. Dunnouk, $\mathrm{PH}$ is the result of the impact of negative environment factors characterized by high population density and poor sanitary conditions, leading to the spread of parasites in the gastrointestinal tract [23, p. 99113]. Stuart-McAdam expressed the opinion that iron deficiency in blood is an adaptive response of the body to chronic pathogenic conditions, i.e. it is considered to be an indicator of increased pathogenic exposure in certain habitats. Pathogens includes fungi, viruses, bacteria and parasites [61].

As already mentioned above, factors leading to $\mathrm{PH}$ on bone remains vary considerably. Nevertheless, in our opinion, the formation of markers of iron-deficiency anemia in the Sarmatians, should be explained by the conception proposed by P. Stuart-Macadam [61].

To confirm this point of view, let us again turn to the Sarmatians' lifestyle, environment conditions and diet habits described in written, ethnographic and archaeological sources. 
Hippocrates, Strabo, Pomponius Mela, Tacitus, and Ammian Martselin describe the lifestyle of many nomadic peoples such as the Scythians, the Sarmatians and the Alans: "...the population is referred to as nomads because they do not have houses, and they live in tents... covered from every side with felt and arranged like houses, they are impenetrable for water (rain), light or winds. ...Only women live in such tents, whereas men ride on horseback; followed by their herds of sheep and cows and flock of horses. They stay in one place as long as there is enough grass to feed the herds, and when it is not sufficient, they move to another place. This is the way of life and customs of the Scythians" [26, Ch. 18; 39, p. 207$212 ; 53]$. "They follow their herds, always choosing the arears better fit for pastures; in winters, they stay by the swamps near Meotian Lake, and in summer on plains" [32]. "The Sarmatians do not live in towns and do not even have permanent residence areas. They always live in a camp, carrying their property and wealth where the best pastures attract them or being forced by retreating or pursuing enemies" [35]. The Sarmatians differ from the Wends because "they do not build houses, but live on a cart and on a horse" [35, p. 222]. "Each of them (the Sarmatian) has a lot of horses, since they are nomads, their land is not divided into plots and nothing will grow there, except for wildly growing trees" [47; 48]. "..., the Alans, living at a distance from each other, like the nomads, migrate around vast arears. They do not have any huts ... live in tents ... . When they come to a place rich in grass, they have their own tents in a circle and eat like animals; having exterminated all the food for cattle, they again carry their own, so to speak, cities, placing them on carts" [47].

The Sarmatians ate, as above-mentioned, mainly animal products, rarely millet porridge. Probably, a large proportion of the Sarmatians' diet consisted of raw products of animal origin. Quintus Ennius writes "...Scythian peoples who at the time of flight or retreat eat horse blood mixed with milk" $[35$, p. 207]. In the conditions of food scarcity or hunger, this method of restoring strength was the only salvation of the Sarmatians. Here is how it is described in the illuminations to Lukan: "The Sarmatians and the Moschis waged a prolonged war and, finally, forced by hunger, mixed the blood of horses with milk in order to be able to drink" [36].
Marcus Aurelius Martial (100AD) in his epigramme writes: "A Sarmat came, gorged with horse blood" [34, p. 319]. Clement of Alexandria (300 AD) in his work "The Teacher" gives similar information about the nomadic Scythians: "...the Scythian rushes wherever he wants, tormented by hunger, he requires food from the horse, the latter gives him his veins and gives his master all that it has - its blood. Thus, a horse for a nomad is a means of transportation and food" [34, p. 281].

Ethnographic studies of the feeding habits of Central Asian nomads indicate that the Scythians, Mongolians, Tibetans, and Kazakhs used fresh meat mainly in autumn during the slaughter period, and the blood (so-called "living blood") of animals was consumed quite often, especially in hiking or during famine periods [67].

In archaeological research, there are proofs of the Sarmatians' nomadic lifestyle and the specifics of their household traditions [58, p. 28; 66, p. $133 ; 59$, p. 33]. Thus, the environmental conditions and lifestyle of the nomads were quite difficult. Cold in winter and heat in the summer, almost constant outdoor exposure and the limited area of the tent, transportation of women and children, created crowding and unsanitary conditions. Besides, specific diet rich in animal products could have provoked the appearance of various parasites in the body. These factors caused stressful conditions for the body and the immune system. We can conclude that anemia in the Sarmatian children develops because of a complex of factors of extreme lifestyle.

Unsanitary conditions contributed to the fact that children and adults developed local foci of specific and non-specific infections. In the overwhelming majority of cases, a whole range of diseases such as hemorrhages, anemia, inflammatory processes or porosis on the bones were simultaneously present in the Sartmatian children. It is almost impossible to determine which disease originated first and which were the consequences. Therefore, multiple pathological conditions on the bone remains of the early Sarmatian children tell us about long-term chronic diseases that occur seasonally during the famine and arguably in winter periods. At the same time, signs of slowly developing chronic conditions and indicators of the body's response to fight them testify to high immune defense levels in the Sarmatian children. 
Regardless of the context and the kind of research conducted on the Sarmatians, the common idea of many scientists is that this people was a formidable military force. Historical, archaeological and anthropological data confirm the evidence of ancient writers about the extreme aggressiveness of the Sarmatian tribes. What does the study of the children's series of early Sarmatians show? Judging by the fact that traumatic lesions on the bone remains of immature individuals of the Early Sarmatian time have not been detected, we can conclude that children most likely did not take part in military campaigns or marches. The war is a matter of young and experienced adults. At the same time, cases of traumatic injuries were detected in adolescent group. The two recorded injuries are not an exhaustive proof of the participation of young people in military events, especially since no weapons were found in the burials of these individuals, so their traumas could well be the result of accidents or trainings. Nevertheless, the very fact of the presence of skull injuries in teenage Sarmatians suggests a possible inclusion of this category of the population in social life. Therefore, for example, the Kyrgyz nomads had a transition from childhood to adulthood at the age of 12. At this point, the child was trusted to graze livestock and to participate in entertainments [1, p. 173]. A similar picture is described in the Kazakhs society. Sexual differentiation begins in the Kazakh nomadic society since 12-13; girls start to practice women's responsibilities whereas boys help their fathers $[63$, p. 123; 3]. In the Ossetians tribes, boys were taught archery at the age of 67 , horse riding at 7-10, and actively participated in various physical contest games since teenage years $[19$, p. 46].

Thus, injuries in the Sarmatian adolescents are likely to reflect a higher social status of this population group, and confirm the inclusion, perhaps partial, in the adult life of the nomadic society.

\section{Conclusion}

The number of children in the early Sarmatian burials indicates a normal demographic picture of the paleopopulation, whereas the peaks of mortality rate in infancy and early childhood show periods when the impact of stress factors are mostly influential. In the early Sarmatians, breastfeeding lasted up to 3-4 years. The basis of the Sarmatian diet was meat and dairy products, which is confirmed by a complex of dental pathologies, spread in both adults and children of the 400-100 BC. The early Sarmatian children were influenced by a combination of negative factors such as cold weather, loss of livestock in winter and famines that occurred every 3-5 years. Meat and milk diet, severe vitamin deficiency enhanced negative influence of the environment and lifestyle, causing scurvy in children. Raw products of animal origin including meat, blood, and by-products led to the spread of parasites in the gastrointestinal tract, which, in turn, caused anemia. Lack of basic sanitation, (according to written sources, only hemp baths existed in the Sarmatians), contributed to the spread of helminthiases and infections among the nomads. Multiple pathological conditions revealed on the bones of children of 400-100 BC indicate their chronic nature, proving efficient immunity response in ancient populations. Children did not participate in combat marches in the early Sarmatian times, which is quite natural. Traumas in adolescents are, most likely, evidence of a more active lifestyle and confirm the partial inclusion in adult life of the nomadic society.

\section{NOTE}

1 The article was prepared within the framework of State task of the Ministry of Education and Science of the Russian Federation, project 33.2830.2017/4.6 "South of Russia in the Early Iron Age: Dialogue of Cultures East-West".

\section{REFERENCES}

1. Abramzon S.M. Kirgizyi ikh etnogeneticheskie $i$ istoriko-kulturnye svyazi [Kirgizi and Their Ethnogenetic and Historical Connections]. Kyrgyzstan, $1990.480 \mathrm{p}$.

2. Armelagos G.J. Health and Disease in Prehistoric Populations in Transition. New York, Bergin and Garvey Publ., 1990. 400 p.

3. Balabanova M.A. Demografiya pozdnikh sarmatov [Demography of Late Sarmatians]. Nizhnevolzhskiy arkheologicheskiy vestnik [The Lower Volga Archaeological Bulletin], 2000, iss. 3, pp. 201-208.

4. Balabanova M.A. Khronologicheskie osobennosti polovozrastnoy struktury sarmatskikh 
grupp Nizhnego Povolzhya [Chronological Features of Sex and Age Groups of Sarmatians in the Lower Volga Region]. Vestnik Volgogradskogo gosudarstvennogo universiteta. Seriya 4, Istoriya. Regionovedenie. Mezhdunarodnye otnosheniya [Science Journal of Volgograd State University. History. Area Studies. International Relations], 2009, no. 1 (15), pp. 5-12.

5. Balabanova M.A., Pererva E.V., et al. Kurgannyy mogilnik Peregruznoe I: rezultaty mezhdistsiplinarnykh issledovaniy [Burial Mound Peregruznoe I: Results of Interdisciplinary Research]. Volgograd, Izd-vo Volgogradskogo filiala RANKhiGS, 2014.359 p.

6. Balabanova M.A., Klepikov V.M., Korobkova E.A., Krivosheev M.V., Pererva E.V., Skripkin A.S. Polovozrastnaya struktura sarmatskogo naseleniya Nizhnego Povolzhya: pogrebalnaya obryadnost $i$ antropologiya: monografiya [Gender and Age Structure of the Sarmatian Population of the Lower Volga Region: Funeral Rites and Anthropology: Monograph]. Volgograd, Izd-vo Volgogradskogo filiala RANKhiGS, 2015.272 p.

7. Balabanova M.A. Strategiya vyzhivaniya v kochevykh obshchestvakh vostochnoy Evropy v drevnosti i v srednevekovye [Survival Strategy in Nomadic Societies of Eastern Europe in Ancient Times and in the Middle Ages]. Ekologiya drevnikh $i$ traditsionnykh obshchestv: Materialy $V$ Mezhdunarodnoy nauchnoy konferentsii [Ecology of Ancient and Traditional Societies: Proceedings of the $5^{\text {th }}$ International Academic Conference]. Tyumen, 2016, iss. 5, pp. 15-18.

8. Batieva E.F. Naselenie Nizhnego Dona $v I X v$. do n.e. - IV v. n.e. (paleoantropologicheskoe issledovanie)[Lower Don Population in the $9^{\text {th }} \mathrm{c}$. BCthe $4^{\text {th }}$ c. AD (Paleoanthropological Research)]. Rostov-on-Don, Izd-vo YuNTs RAN, 2011. 160 p.

9. Baustian K.M. Health status of infants and children from the Bronze Age tomb at Tell Abraq, United Arab Emirates. Dissertation Theses. Capstones, 1988. 355 p.

10. Bichurin H.Ya. Sobranie svedeniy o narodakh, obitavshikh v Sredney Azii v drevnie vremena [Collection of Information about Peoples that Lived in Central Asia in Ancient Times]. Moscow, 1950, vol. 1. $231 \mathrm{p}$.

11. Bogatenkov D.V., Drobyshevskiy S.V. Antropologiya [Anthropology]. URL: https:// studfiles.net/preview/431161/. (accessed March 9, 2018).

12. Brickley M., Ives R. Skeletal Manifestations of Infantile Scurvy. American Journal of Physical Anthropology, 2006, vol. 129, pp. 163-172.

13. Brothwell D.R. Digging up Bones. London, Trustees of British Museum, 1972. $316 \mathrm{p}$.
14. Brown M., Ortner D.J. Childhood Scurvy in a Medieval Burial from Mačvanska Mitrovica, Serbia. International Journal of Osteoarchaeology, 2011, no. 21, pp. 197-207.

15. Buckley H.R. Subadult health and disease in prehistoric Tonga, Polynesia. American Journal of Physical Anthropology, 2000, no. 113(4), pp. 481-505.

16. Buzhilova A.P. Drevnee naselenie: (Paleopatologicheskie aspekty issledovaniya) [The Ancient Population: Paleopathological Aspects of Study]. Moscow, Izd-vo IA RAN, 1995. 189 p.

17. Buzhilova A.P., Kozlovskaya M.V., Lebedinskaya G.V., Mednikova M.B. Istoricheskaya ekologiya cheloveka [Historical Human Ecology]. Moscow, Staryy sad Publ., 1998. 260 p.

18. Buzhilova A.P. Anemiya u drevnego naseleniya kak odin iz indikatorov okruzhayushchey sredy: Analiz osteologicheskikh markerov [Anemia in the Ancient Population as One of the Environmental Indicators: Analysis of Osteological Markers]. Vestnik antropologii [Anthropology Bulletin], 2001, iss. 7, pp. 227-236.

19. Callagova Z.B. Osetinskaya traditsionnaya kultura vospitaniya [Ossetian Traditional Culture of Education]. Izvestiya SOIGSI, 2014, no. 14(53), pp.41-49.

20. Crandall J.J., Haagen D.Kl. Advancements, challenges, and prospects in the paleopathology of scurvy: Current perspectives on vitamin C deficiency in human skeletal remains. International Journal of Paleopathology, 2014, vol. 5, pp. 1-8.

21. Demkin V.A. Demkina T.S. Vozmozhnosti rekonstruktsii pogrebalnoy pishchi v keramicheskikh sosudakh iz kurganov bronzovogo i rannezheleznykh vekov [Reconstruction of Burial Food in Ceramic Vessels from Burial Mounds of the Bronze and Early Iron Ages]. Etnograficheskoe obozrenie [Ethnographic Review], 2000, no. 4, pp. 73-81.

22. Dobrovolskaya M.V. Naselenie epokhi bronzy v Prikubanye: Nekotorye aspekty izucheniya antropologicheskogo istochnika [The population of the Bronze Age in the Kuban: Some Aspects of the Study of Anthropological Source]. OPUS: Mezhdistsiplinarnye issledovaniya $v$ arkheologii. Sbornik statey [OPUS: Interdisciplinary Research in Archaeology. Digest of Articles]. Moscow, Izd-vo IA RAN, 2005, iss. 4, pp. 95-112.

23. Dunn F.L. Intestinal parasitism in Malayan aborigines (Orang Asli). Bulletin of the World Health Organization, 1972, no. 46, pp. 99-113.

24. Fuchs K., Berezena N., Gresky Ju. Scurvy malnutrition in the Caucasian bronze age. $C A U$ "Human development in landscapes". URL: https://www. academia.edu/3390094/Scurvy___Malnutrition_in_ the_Caucasian_Bronze_Age. (accessed March 9, 2018).

25. Gippokrat. Izbrannye knigi. O vozdukhe, vodakh i mestnostyakh [Selected Books. On Air, Water and Areas]. Moscow, 1994, pp. 275-307. 
26. Goodman A.H., Armelagos G.J. Childhood stress and decreased longevity in a prehistoric population. American Anthropology, 1988, no. 90, pp. 936-944.

27. Halcrow S.E., Harris N.J., Beavan N., Buckley H.R. First bioarchaeological evidence of probable scurvy in Southeast Asia: Multifactorial etiologies of vitamin $\mathrm{C}$ deficiency in a tropical environment. International Journal of Paleopathology, 2014, no. 5, pp. 63-71.

28. Hazanov A.M. Sotsialnaya istoriya skifov [Social History of the Scythians]. Moscow, 1975. 149 p.

29. Hengen O.P. Cribra orbitalia: Pathogenesis and probable etiology. Homo, 1971, no. 22, pp. 57-75.

30. Huss-Ashmore R.A., Goodman A.H., Armelagos G.J. Nutritional inferences from paleopathology. Adv. Archeol. Method Theory, 1982, no. 5, pp. 395-474.

31. Klavdij Jelian. O zhivotnyh [About Animals]. Vestnik drevney istorii [Journal of Ancient History], 1948, no. 2 (24), pp. 223-227.

32. Kliment Aleksandrijskij. Pedagog [Teacher]. URL: http://www.magister.msk.ru/library/bible/comment/ clementa/clima01.htm. (accessed March 9, 2018).

33. Kufterin V.V. Paleopatologiya detey i podrostkov Gonur-Depe(Turkmenistan) [Paleopathology of Children and Adolescents in Gonur Depe (Turkmenistan)]. Vestnik arkheologii, antropologii i etnografii [Journal of Archaeology, Anthropology and Ethnography], 2016, no. 1(32), pp. 91-100.

34. Latyshev V.V. Izvestiya drevnikh pisateley o Skifii i Kavkaze [News of Ancient Writers about Scythia and Caucasus]. Vestnik drevney istorii [Journal of Ancient History], 1948, no. 2 (24), no 3 (25).

35. Latyshev V.V. Izvestiya drevnikh pisateley o Skifii i Kavkaze [News of Ancient Writers about Scythia and Caucasus]. Vestnik drevnei istorii [Journal of Ancient History], 1949, no. 2 (28), no. 3 (29), pp. 207-235.

36. Lukan Mark Annej. Farsaliya, ili Poema o grazhdanskoy voyne [Pharsalus, or Poem about Civil War]. Transl. by L.E. Ostroumova. Moscow, Ladomir Publ.; Nauka Publ., 1993. 348 p.

37. Maat G.J.R. Scurvy in Adults and Youngsters: the Dutch Experience. A Review of the History and Pathology of a Disregarded Disease. International Journal of Osteoarchaeology, 2004, no. 14, pp. 77-81.

38. Makarov N.A., Zakharov S.D., Buzhilova A.P. Srednevekovoe rasselenie na Belom ozere [The Medieval Settlement on the White Lake]. Moscow, Yazyki Russkoy kultury Publ., 2001. 495 p.

39. Marcellin Ammian. Rimskaya istoriya [Roman History]. Saint Petersburg, Aleteya Publ., 1994. 559 p.

40. Mays S.A Likely Case of Scurvy from Early Bronze Age Britain. International Journal of Osteoarchaeology, 2008, no. 18, pp. 178-187.
41. Mednikova M.B. Antropologiya rannikh skifov: mogilnik Novozavedennoe II [Anthropology of Early Scythians: Burial Mound Novozavedennoe II]. OPUS: Mezhdisciplinarnye issledovaniya $v$ arkheologii. Sbornik statey [OPUS: Interdisciplinary Research in Archaeology. Collected Articles]. Moscow, Izd-vo IA RAN, 2002, iss. 1-2, pp. 128-140.

42. Melikian M., Waldron T. An Examination of Skulls from Two British Sites for Possible Evidence of Scurvy. International Journal of Osteoarchaelogy, 2003, vol. 7, pp. 207-212.

43. Mensforth, R., Lovejoy C., Lallo H., Armelagos G. The Role of Constitutional Factors, Diet and Infectious Disease in the Etiology of Porotic. Hyperostosis and Periosteal Reactions in Prehistoric Infants and Children. Medical Anthropology, 1978, no. 2, pp. 1-59.

44. Nebolsin P. Ocherki byta kalmykov Hoshoutovskogo ulusa [Essays on the Life of Kalmyks in Hoshoutovsky Ulus]. Saint Petersburg, 1852. 47 p.

45. Ortner D.J., Ericksen M.F. Bone Changes in the Human Skull Probably Resulting from Scurvy in Infancy and Childhood. International Journal of Osteoarchaeology, 1997, vol. 7, pp. 212-220.

46. Ortner D.J., Butler Wh., Cafarella J., Millian L. Evidence of probable Scurvy in Subadults From Archeological Sites in north America. American journal of Physical anthropology, 2001, no. 114, pp. 343-351.

47. Ovidij Publij Nazon. Pisma s Ponta [Letters from Pontus]. Saint Petersburg, Studia Biografika Publ., 1994, vol. 1, pp. 341-432.

48. Pavsanij. Opisanie Jellady [Description of Greece]. Transl. by S.P. Kondratyev. Saint Petersburg, Aleteya Publ., 1996, vol. 1. 336 p.

49. Pererva E.V. Paleopatologicheskie osobennosti naseleniya Nizhnego Povolzhya iz podkurgannykh zakhoroneniy epokhi ranney bronzy [Paleopathological Characteristics of the Population of the Lower Volga Region from Under-Barrow Burials of the Early Bronze Age]. Izvestiya VGPU [Proceedings of the Volgograd State Social and Pedagogical University], 2013, no. 8 (83), pp. 47-53.

50. Pererva E.V. K voprosu o paleopatologicheskikh osobennostyakh nepolovozrelogo i podrostkovogo naseleniya epokhi bronzy iz podkurgannykh zakhoroneniy Nizhnego Povolzhya [On the Paleopathological Features of Immature and Adolescent Population of the Bronze Age Under-Barrow Burials in the Lower Volga]. Ekologiya drevnikh i traditsionnykh obshchestv: Materialy V Mezhdunarodnoy nauchnoy konferentsii [Ecology of Ancient and Traditional Societies: Proceedings of the $5^{\text {th }}$ International Academic Conference], 2016, iss. 5, pp. 51-57.

51. Pererva E.V. Paleopatologicheskie osobennosti nepolovozrelogo i podrostkovogo 
naseleniya srednesarmatskogo vremeni, pogrebennogo v mogilnikakh Nizhnego Povolzhya [Paleopathological Features of the Immature and Adolescent Population of Middle Sarmatian Time Buried in Mounds the Lower Volga Region]. Genesis: Istoricheskie issledovaniya [Genesis: Historical Studies]. Moscow, NB-mediya Publ., 2016, no. 6, pp. 206-220.

52. Pliny the Elder. Estestvennaya istoriya [Natural History]. Transl. by N.M. Podzemskaya. Antichnaya geografiya [Ancient Geography]. Moscow, Geografgiz Publ., 1953, pp. 238-262.

53. Pomponius Mela. Mestopolozhenie zemli [Land Location]. Transl. by S.K. Apta. Antichnaya geografiya [Ancient Geography]. Moscow, Geografgiz Publ., 1953, pp. 176-238.

54. Puteshestvie v vostochnye strany Plano Karpini i Rubruka [Carpini and Rubruk's Journey to the East Plano]. Moscow, 1957, pp. 95-96.

55. Romanova G.P. Opyt paleodemograficheskogo analiza usloviy zhizni naseleniya stepnykh rayonov Stavropolya $\mathrm{v}$ epokhu ranney bronzy [Experience of Paleodemographic Analysis of Living Conditions in the Steppe Regions of the Stavropol Region in the Early Bronze Age]. Voprosy antropologii [Anthropology Questions], 1989, iss. 82, pp. 67-77.

56. Shults M., Kozak A.D. Morfologiya i klassifikatsiya sledov meningialnykh reaktsiy na drevnikh cherepakh (problemy diagnostiki na primere srednevekovykh populyatsiy Kieva) [Morphology and Classification of Traces of Meningeal Reactions in Ancient Turtles (Problems of Diagnosis on the Example of Kiev Medieval Populations)]. OPUS: Mezhdistsiplinarnye issledovaniya $v$ arkheologii [OPUS: Interdisciplinary Research in Archaeology]. Moscow, Izd-vo IA RAN, 2008, iss. 6, pp. 276-300.

57. Sinnott C.A. A Bioarchaeological and historical analysis of scurvy in eighteenth and nineteenth century England. A thesis submitted for the degree of doctor of philosophy. Cranfield University, 2013. 279 p.

58. Skripkin A.S. Aziatskaya Sarmatiya. Problemy khronologii i ee istoricheskiy aspekt [Asian Sarmatia. Problems of Chronology and Its Historical Aspect]. Saratov, Izd-vo Sarat. University, 1990. 299 p.

59. Smirnov K.F. Sarmaty Nizhnego Povolzhya i mezhdurechya Volgi i Dona v IV v. do n.e. - II v. do n.e. (istoriko-arkheologicheskiy ocherk) [Sarmatians of the Lower Volga Region and the Volga-Don Interfluve in the $4^{\text {th }}$ c. BC. $-2^{\text {nd }}$ c. AD (Historical and Archaeological Survey)]. Sovetskaya etnografiya [Soviet Ethnography], 1974, no. 3, pp. 33-45.

60. Strabon. Geografiya: v $17 \mathrm{kn}$. [Geography: in 17 Books]. Transl. by G.A. Stratanovsky. Moscow, Ladomir Publ., 1994. 944 p.

61. Stuart-Macadam P. Porotic Hyperostosis: A New Perspective. American Journal of Physical Anthropology, 1992, no. 87, pp. 39-47.

62. Suby J.A. Porotic hyperostosis and cribra orbitalia in human remains from southern Patagonia. Anthropological Science, 2014, vol. 122 (2), pp. 69-79.

63. Sunduy G.D. Mir detstva kochevoy Azii: opyt dukhovno-nravstvennogo vospitaniya [World of Childhood of Nomadic Asia: Experience of Spiritual and Moral Education]. Kyzyl, Institut razvitiya natsionalnoy shkoly, 2009. $168 \mathrm{p}$.

64. Waldron T. Paleopathology. New York, Cambridge University Press, 2009. 299 p.

65. Walker Ph.L., Bathurst R., Richman R., Gjerdrum Th., Andrushko V.A. The Cause of Porotic Hyperostosis and Cribra Orbitalia: A Reappraisal of the Iron-Deficiency Anemia Hypothesis. American Journal of Physical Anthropology, 2009, no. 139, pp. 109-125.

66. Zhelezchikov B.F. Rannie kochevniki Yuzhnogo Priuralya: diss. d-ra ist. nauk [Early Nomads of the Southern Urals. Dr. hist. sci. diss.]. Moscow, 1979. 189 p.

67. Zhitetskiy I.A. Astrakhanskie kalmyki (nablyudeniya $i$ zametki) [Astrakhan Kalmyks (Observations and Notes)]. Astrakhan, 1892, pp. 192-195.

68. Zhukovskaya N.L. Pishcha kochevnikov Tsentralnoy Azii (K voprosu ob ekologicheskikh osnovakh formirovaniya modeli pitaniya) [Food of Nomads of Central Asia (the Question of Environmental Basis of the Formation of the Power Model)]. Sovetskaya etnografiya [Soviet Ethnography], 1979, no. 5, pp. 65-75.

69. Zuckermana M.K., Garofalob E.M., Frohlichc V, Ortner D.J. Anemia or scurvy: A pilot study on differential diagnosis of porous and hyperostotic lesions using differential cranial vault thickness in subadult humans. International Journal of Paleopathology, 2014, no. 5, pp. 27-33. 


\section{Information about the Authors}

Evgeniy V. Pererva, Candidate of Sciences (History), Director of Scientific Department, Volgograd Institute of Management - Branch of the Russian Presidential Academy of National Economy and Public Administration, Gagarina St., 8, 400131 Volgograd, Russian Federation, perervafox@mail.ru, https://orcid.org/0000-0001-8285-4461

Valentina Yu. Chistobaeva, Laboratory Assistant, Laboratory of Archaeological Research, Volgograd State University, Prosp. Universitetsky, 100, 400062 Volgograd, Russian Federation, v.chistobaeva@volsu.ru,https://orcid.org/0000-0001-7946-3144

\section{Информация об авторах}

Евгений Владимирович Перерва, кандидат исторических наук, начальник научно-организационного отдела, Волгоградский институт управления - филиал Российской академии народного хозяйства и государственной службы при Президенте Российской Федерации, ул. Гагарина, 8, 400131 г. Волгоград, Российская Федерация, perervafox@mail.ru, https://orcid.org/00000001-8285-4461

Валентина Юрьевна Чистобаева, лаборант, Лаборатория археологических исследований, Волгоградский государственный университет, просп. Университетский, 100, 400062 г. Волгоград, Российская Федерация, v.chistobaeva@volsu.ru, https://orcid.org/0000-0001-7946-3144 